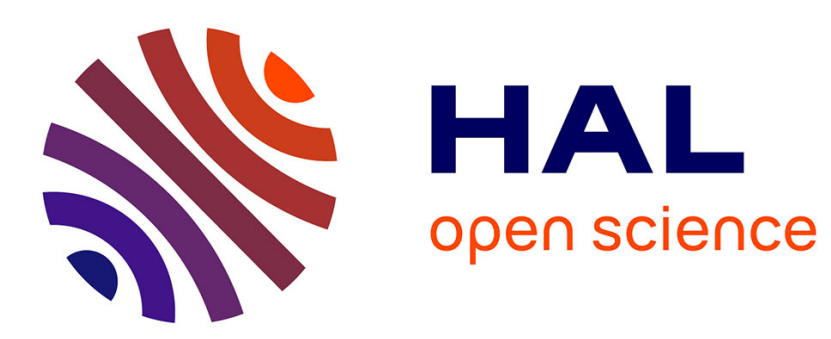

\title{
Genetic hemochromatosis: Pathophysiology, diagnostic and therapeutic management
}

P. Brissot, T. Cavey, M. Ropert, P. Guggenbuhl, Olivier Loréal

\section{To cite this version:}

P. Brissot, T. Cavey, M. Ropert, P. Guggenbuhl, Olivier Loréal. Genetic hemochromatosis: Pathophysiology, diagnostic and therapeutic management. La Presse Médicale, 2017, 46 (12), pp.e288-e295. 10.1016/j.lpm.2017.05.037 . hal-01671715

\section{HAL Id: hal-01671715}

\section{https://hal-univ-rennes1.archives-ouvertes.fr/hal-01671715}

Submitted on 19 Jun 2018

HAL is a multi-disciplinary open access archive for the deposit and dissemination of scientific research documents, whether they are published or not. The documents may come from teaching and research institutions in France or abroad, or from public or private research centers.
L'archive ouverte pluridisciplinaire HAL, est destinée au dépôt et à la diffusion de documents scientifiques de niveau recherche, publiés ou non, émanant des établissements d'enseignement et de recherche français ou étrangers, des laboratoires publics ou privés. 


\section{TITLE PAGE}

Title. Genetic hemochromatosis: Pathophysiology, Diagnostic and Therapeutic Management

AUTHORS : Brissot Pierre ${ }^{(1,2)}$, Cavey Thibault ${ }^{(2,3)}$, Ropert Martine ${ }^{(2,3)}$, Guggenbuhl Pascal $^{(2,4)}$, Loréal Olivier ${ }^{(2)}$

AFFILIATIONS :

(1) University of Rennes 1, Hepatology. Faculty of medicine.. Rennes (France)

(2) Inserm-UMR 991. Rennes (France)

(3) CHU Rennes, Department of specialized biochemistry. . Rennes (France)

(4) CHU Rennes, Department of rheumatology.. Rennes (France)

WORD COUNT : 3159

CORRESPONDING AUTHOR:

Prof. Pierre BRISSOT. pierre.brissot@univ-rennes1.fr

\section{ACKNOWLEDGEMENTS}

The authors wish to thank the FFAMH, EFAPH, and AFeMERS associations for financial support.

\section{DISCLOSURE OF INTEREST}

PB has received honoraria for occasional consulting and lectures from Novartis laboratories. 


\title{
Résumé
}

Le terme d'hémochromatose $(\mathrm{HC})$ correspond à plusieurs affections caractérisées par une surcharge en fer systémique d'origine génétique, affectant qualité et espérance de vie. Les importantes avancées récentes dans la compréhension du métabolisme du fer permettent de diviser ces affections en deux grandes catégories physiopathologiques. Pour la plupart des HC (types1, 2, 3, et 4B) la surcharge en fer est la conséquence d'un manque cellulaire en hepcidine à l'origine d'une hypersidérémie puis de l'apparition de fer non lié à la transferrine plamsatique. En contraste, dans l'HC de type 4A, l'excès en fer est la conséquence d'un défaut de passage dans le courant sanguin du fer macrophagique. Quel que soit le type d'HC, le diagnostic repose désormais sur une stratégie non invasive combinant données cliniques, biologiques et d'imagerie. La base du traitement demeure les saignées avec la perspective, dans les HC par déficit en hepcidine, de la supplémentation en cette hormone. La prévention de l'HC est cruciale à l'échelon de la famille et, dans le cas de l'HC de typel, demeure un objectif majeur, quoiqu'encore débattu, au niveau de la population.

\begin{abstract}
The term hemochromatosis (HC) corresponds to several diseases characterized by systemic iron overload of genetic origin and affecting both the quality of life and life expectancy. Major improvement in the knowledge of iron metabolism permits to divide these diseases into two main pathophysiological categories. For most $\mathrm{HC}$ forms (types 1, 2, 3 and 4B HC) iron overload is related to cellular hepcidin deprivation which causes an increase of plasma iron concentration and the appearance of plasma non-transferrin bound iron. In contrast, iron excess in type 4A ferroportin disease, is related to decreased cellular iron export. Whatever the $\mathrm{HC}$ type, the diagnosis rests on a non invasive strategy, combining clinical, biological and imaging data. The mainstay of the treatment remains venesection therapy with the perspective
\end{abstract}


of hepcidin supplementation for hepcidin-deprivation related HC. Prevention of HC is critical at the family level and, for type $1 \mathrm{HC}$, remains a major goal, although still debated, at the population level. 
Genetic hemochromatosis: Pathophysiology, Diagnostic and Therapeutic management

The term genetic hemochromatosis ( $\mathrm{HC})$ has become a generic one, encompassing a variety of disorders corresponding to systemic iron overload of genetic origin. Therefore, today, one should now think in terms of «hemochromatoses» rather than «hemochromatosis». Numerous mutations, located on different chromosomes, are involved, leading to varying phenotypes according to clinical expression and severity. The present review will focus on HFE-related (type 1) HC (chromosome 6), by far the most frequent form in Caucasians, and on the non-HFE related HC, rare diseases involving mutations of the hemojuvelin(1) (HFE2 or HJV) (chromosome 1), hepcidin(2) (HAMP) (chromosome 19), transferrin receptor2(3) (chromosome 7) (TFR2), ferroportin(4, 5) (SLC4OA1) (chromosome 2) and ceruloplasmin $(C P)$ (chromosome 3) genes, and corresponding to types 2A, 2B, 3, $4 \mathrm{HC}$, and to hereditary aceruloplasminemia(6) (HA), respectively $(7,8)$.

1. Pathophysiology

1.1.It will consider four main aspects(9) (Figs. 1 and 2)

1.2. Hemochromatoses with iron overload due to enhanced cellular iron influx related to deprivation in hepcidin

1.2.1. Mechanisms of hepcidin cellular deprivation. Hepcidin (encoded by the HAMP gene) is the iron hormone governing systemic iron homeostasis. Essentially produced by the hepatocytes(10), this 25 aminoacid peptide decreases plasma iron by a double mechanism(11). On the one hand, it limits digestive iron absorption, on the other hand it decreases iron release from the spleen into the plasma (this splenic iron originates from the 
normal erythrophagocytotic process). Hepcidin modulates the amount of iron release into the plasma by targeting ferroportin, the only known cellular iron exporter, (12). Schematically, after hepcidin binding to ferroportin, the complex is internalized and leads to intracellular ferroportin degradation which, in turn, decreases the iron export capacity mediated by the residual ferroportin at the membrane level(13). Therefore, every physiological or pathological situation increasing hepcidin synthesis will decrease plasma iron, and conversely.

The development of iron overload in hepcidin deprivation-related HC is mediated by plasma iron increase (hypersideremia), through two mechanisms.

The most frequent one is hypohepcidinemia. It is the case for types 1 (HFE related), 2A (HFE2 or $H J V$ - related), and type 3 (TFR2 - related) HC. In these settings, the causal mutations, through alteration of molecular cascades that are increasingly dissected, and involve especially the BMP-SMAD signaling pathway and/or ERK1/2 patways (14), lead to abnormally decrease hepatic synthesis of hepcidin with respect to iron status, and subsequently to decrease levels of plasma hepcidin.

The other situation implicated in hepcidin cellular «deprivation» is hepcidin resistance. It occurs during type $\mathrm{B}$ ferroportin disease, due to very specific mutations and characterized by an impaired capacity of ferroportin to interact with hepcidin. Hepcidin being then unable to decrease ferroportin expression, the cellular consequences are equivalent to those observed during plasma hepcidin deficiency with a resulting increase efflux of iron from the enterocytes and from the splenic macrophages, and therefore increased plasma iron levels.

1.2.2. Pathophysiological consequences of hepcidin cellular deprivation. 
The key primary biochemical event is increased plasma iron concentration which leads to increased saturation of transferrin, the physiological carrier protein of plasma iron (corresponding to transferrin saturation -TfSat- levels over 45\%). As a result, novels forms of circulating iron may appear in the plasma, named nontransferrin bound iron (NTBI). NTBI, in contrast with transferrin-iron that targets essentially the bone marrow, is very avidly taken up by parenchymal cells, first and foremost the hepatocytes(15) but also cardiomyocytes and. pancreatic cells. Therefore, NTBI is the major iron species accounting for cellular (and tissue) iron deposition in HC. Moreover, whenever TfSat exceeds 75\%(16), a novel NTBI form appears, defined by its capacity to produce reactive oxygen species (ROS), and called labile plasma iron (LPI)(17) or reactive plasma iron (RPI). LPI is considered as the main culprit for cellular iron toxicity in $\mathrm{HC}$, through damaging cellular plasma membranes as well as intracellular organelles. The resulting tissue alterations underly the clinical organ damage developed in HC, such as hepatic, pancreatic and cardiac lesions.

1.3.Hemochromatoses with iron overload due to decreased cellular iron efflux related to ferroportin deficiency

1.3.1. Mechanisms of ferroportin deficiency. The involved mutations of the ferroportin gene affect the cellular iron export function and not the domain interacting with hepcidin, . As a consequence, cellular iron egress is impaired, leading to increased intracellular iron stores. Such a situation is present in type $4 \mathrm{~A} \mathrm{HC}$, which is the most frequent form of the ferroportin disease $(4,5)$.

1.3.2. Pathophysiological consequences of ferroportin deficiency 
As a consequence of altered cellular iron egress, plasma iron does not TfSat, respectively). Therefore, no plasma NTBI is present, implying that parenchymal cells are only moderately affected by iron deposition, especially as ferroportin activity is particularly pronounced in macrophages. The sites of cellular iron overload are therefore mainly the spleen (particularly rich in macrophages) and, at a lesser degree, the liver (kupffer cells). The absence of NTBI also means absence of LPI and, therefore, less damaging capacity of excessive stored iron (especially as macrophages are less sensitive to iron-related damage than parenchymal cells). These data likely explains why type 4A HC seems a relatively begnin disease as compared to the hepcidin deprivation-related forms of HC(18). However, long-term studies remain to be conducted.

\subsection{Hemochromatosis of not fully solved pathophysiology}

It is the case for HA (19). The proposed explanation for iron overload is iron retention due loss of ferroxidase activity normally exerted by ceruloplasmin(20). Indeed, this ferroxidase property is required for plasma transferrin to take up the iron released, under the ferrous form, from the cells (iron oxidation into its ferric form being needed for transferrin uptake). As an upstream consequence, ferroportin activity for cellular iron export would be altered, leading to cellular iron retention (as in type $4 \mathrm{~A}$ ferroportin disease). This would fit with the decreased plasma iron levels (and TfSat) observed in HA. However, this mechanism cannot not explain why, in HA, iron overload spares the spleen and affects essentially the hepatocytes (like in hepcidin deprivation-related HC)(9). Moreover, $\mathrm{HA}$ is the sole $\mathrm{HC}$ form where iron overload is significantly present in 
the brain, accounting for neurological manifestations of the disease. Further studies are therefore needed to fully elucidate the mechanisms whereby systemic (including brain) iron overload develop in this disease.

1.5.The issue of penetrance variability. It has become clear that genetic predisposition does not mean clinical expression. This is particularly clear in type $1 \mathrm{HC}$ where it has been estimated that $1 \%$ of women and less than $30 \%$ of $C 282 Y / C 282 Y$ men would develop the full-blown disease(21). Many studies are underway to determine the environmental and host factors likely to account for phenotypic variability, which concerns not only the amount of body iron excess, but also, for an equivalent amount of iron overload, the organ targeting of iron excess. Among environmental factors, dietary iron content, physiological iron losses (menstruations(22), pregnancies, breastfeeding), body weight(23) have been identified. Among host factors, the role of male gender (through the hepcidin decreasing effect of testosterone $(24,25)$.has been proposed for favoring greater higher stores as compared to females, and genetic factors have been reported for explaining visceral complications, especially PCSK7 polymorphism for favoring hepatic fibrosis(26)) have been reported.

\section{Diagnostic management}

It is based on a non invasive strategy, i.e. not requiring in most cases to perform a liver biopsy. Five main diagnostic steps can be individualized(27) (Fig.3).

\subsection{To suspect iron overload}

2.1.1. From the clinical viewpoint, many symptoms, more or less associated, can reflect HC. Chronic fatigue, joint pains, hyperpigmentation (melanodermia), impotence, diabetes, osteoporosis, hepatic features (mild 
increase of plasma transaminase activities, hepatomegaly, sometimes cirrhosis or hepatocellular carcinoma), cardiac symptoms (rhythm disturbances, heart failure). Anemic syndrome and neurological symptoms (extrapyramidal syndrome, cognitive dysfunction) can express HA.

When comparing the clinical expression of the various HC types, the following remarks can be proposed : i) Type $1 \mathrm{HC}$ is most often a delayed disease, with a long clinically asymptomatic phase until the age of approximately $30-40$ years in men and $40-50$ in women ; ii) Types $2 \mathrm{~A}$ and 2B (and sometimes type 3) HC correspond to much rarer but also more severe diseases with clinical expression before the age of 30 , and often before 20. They are characterized by severe lesions of the liver (cirrhosis), heart (cardiac failure), and endocrines (hypothalamic-pituitary insufficiency) ; iii) type 4A ferroportin disease is only clinically mildly symptomatic despite strong iron overload.

2.1.2. From the biochemical viewpoint, the most frequent abnormality leading the clinician to suggest iron overload is, by far, hyperferritinemia (usually defined by plasma ferritin levels over $300 \mu \mathrm{g} / \mathrm{L}$ in men, and over $200 \mu \mathrm{g} / \mathrm{L}$ in women). It is critical, however, to remember that hyperferritinemia may be due to other causes than iron excess(28). The main differential diagnosis is the metabolic syndrome. Dysmetabolic hyperferritinemia(29) is probably the most frequent cause of hyperferritinemia worldwide. It should be suspected in any patient with an increase of weight (or waist circumference), blood pressure, glycemia, lipidemia, or uricemia. Plasma TfSat is normal and hepatic iron overload (when assessed by magnetic resonance imaging -MRI-) is normal or only moderately increased(30) (less 
than three times the upper normal limit). Two other possible causes of hyperferritinemia should be ruled out, inflammation and alcoholism(31). It is only after having excluded these three major causes, that increased plasma ferritin levels can be considered as reliably reflecting body iron excess.

With regard to plasma iron or TfSat, it is important to recall that it can be normal or even low, despite significant body iron excess, in $\mathrm{HC}$ forms such as type 4A ferroportin disease and HA.

\subsection{To confirm iron overload}

It is valuable to get a direct visualization of tissue iron overload. For this purpose, hepatic MRI has replaced liver biopsy. Some techniques corespond to relaxometry approaches $(32,33)$, defining indices such as $\mathrm{T} 2 *$ or $\mathrm{R} 2 *$. A simple and reliable method is based on the signal intensity ratio(34). The decreased T2 hepatic signal (as compared the spinal muscle signal which serves as a reference) is inversely correlated with the increase in hepatic iron concentration (the darker the liver, the higher the hepatic iron concentration). «Iron-MRI» also allows to assess the iron status of the spleen and pancreas (and, with relaxometry techniques, of the heart). A further important MRI information is provided by comparing the liver and spleen signals(9). Schematically a «black» liver together with a «white» spleen orientates toward a type of $\mathrm{HC}$ with hepcidin deprivation, whereas a «black» spleen together with a «grey» liver favours the usual (type A) form of ferroportin disease. Therefore, iron-MRI not only ascertains and quantifies iron overload but, by showing the iron balance between liver and spleen, provides a valuable indication on the pathophysiology of iron overload development, an important clue for approaching the $\mathrm{HC}$ type. 
2.3. To suspect the genetic nature of iron overload

2.3.1. An acquired form of iron overload is usually easily ruled out. Transfusional iron overload is obvious in the context of chronic anaemia such as haemoglobinopathies (thalassaemias(35, 36), sickle cell disease(37)), myelodysplastic syndromes(38) or aplastic anaemia related to bone marrow transplantation procedure(39). Similarly, iron overload due to excessive parenteral iron supplementation(40) is diagnosed by the detailed patient's history.

2.3.2. Family data indicating problems of iron excess is another important clue in favor of a genetic disease.

2.4.To orientate toward the pathophysiological category of $\mathrm{HC}$

Combining plasmaTfSat and imaging data is here essential.

2.4.1. Tfsat is a pivotal diagnostic parameter, since increased TfSat favours hepcidin deprivation-related $\mathrm{HC}$, whereas normal or low values are observed in the usual form of ferroportin disease and in HA.

2.4.2. MRI is also, as previously mentioned, an interesting indicator by establishing an iron balance between liver and spleen, thus suggesting hepcidin deficiency or decreased macrophage iron release.

\subsection{To definitely identify the genetic $\mathrm{HC}$ type}

Guided by the combination of clinical, biological, and imaging data, the final diagnostic step is appropriate genetic testing.

\subsubsection{HFE-related HC}

It corresponds, in the vast majority of cases, to $C 282 Y$ (new nomenclature p.Cys.282Tyr) homozygosity (C282Y/C282Y). As to the other HFE mutations, the following statements can be proposed: i) The $H 63 D$ 
(His63Asp) mutation is a simple polymorphism; ii) Compound heterozygosity (C282Y/H63D) or H63D homozygosity are not susceptible to cause significant body iron overload unless they are associated with factors such as alcoholism, the metabolic syndrome, or other mutations impacting iron metabolism gene (digenism) (41) ; iii) The $S 65 C$ mutation has no diagnostic interest; iv) Exceptional profiles of compound heterozygosity can be responsible for clinically overt forms of $\mathrm{HC}$.

\subsubsection{Non-HFE $\mathrm{HC}(42)$}

They are rare diseases, with a reserve for type $4 \mathrm{~A} \mathrm{HC}$ (type A ferroportin disease) that may be more frequent than initially thought (probably related to its dominant mode of transmission)(43). The corresponding specific genetic testing requires duly accredited laboratories(41). It should be noticed that, for HA, it is good clinical practice to check that plasma ceruloplasmin levels are very low or not detectable and/or ferroxidase activity is decreased before performing specific genetic testing. The new technical approach resorting to high throughput sequencing (NGS: next generation sequencing) offers the advantage of its power but should not lead to forget the need for a preliminary clinical orientation, at best managed by clinical reference centers. Moreover, it presents the drawback to identify an increasing number of new mutations whose deleterious nature is often difficult to establish and requiring additional family and/or functional studies(44) .

3. Therapeutic management

It will be confined here to the management of iron removal(27) (Fig.4) 


\subsection{Treatment of HFE (type 1) HC}

3.1.1. Venesections (phlebotomies) remain the key procedure. By removing total blood, they remove red blood cells which contain half the total quantity of body iron $(2 \mathrm{~g})$, and lead the body to pump iron into its reserves in order to produce new erythrocytes. The induction phase usually consists of weekly venesections $(7 \mathrm{~mL} / \mathrm{kg}$ body weight without exceeding $550 \mathrm{~mL})$ until plasma ferritin reaches approximately $50 \mu \mathrm{g} / \mathrm{L}(45)$, provided haemoglobin levels remain superior to $11 \mathrm{~g} / \mathrm{dL}$ (or do not fall more than $2 \mathrm{~g}$ from the baseline levels). Thereafter starts the maintenance treatment, theoretically for life, whose goal is to prevent recurrence of iron overload by maintaining ferritin levels around $50 \mu \mathrm{g} / \mathrm{L}$. It usually requires one venesection every one to 3 months. Checking plasma TfSat has no interest during the major part of the induction phase since this parameter, in contrast with plasma ferritin levels, does not fall until the very end of this phase. During maintenance therapy, it may be advised to monitor TfSat for instance twice a year in order to ensure that the patient does not exhibit a biological profile permanently marked by the contrast between satisfactory ferritin levels and a strong rise in transferrin saturation (especially over $75 \%$, a threshold that may correspond to some risk of iron toxicity due to the presence of LPI). In terms of global results, venesection therapy is simple, cheap, efficient, and well tolerated. Some limitations, however, should be pointed out: i) efficiency may only be partial when organ lesions were too severe when starting the treatment (arthropathy, liver cirrhosis with the persistent risk of liver cancer despite appropriate iron removal) ; ii) tolerance is not devoid of side effects affecting the quality of life (discomfort of the needle puncture especially)(46). 
3.1.2. Erythocytapheresis; This method is to remove only red blood cells. Rarely used, it is more complex and expensive than venesections, but more efficient, and globally well accepted by the patients(47). It can be particularly suitable for people whose professional activity (frequent travelers) is not conducive to frequent repeated bleedings.

3.1.3. Iron chelation. It can be discussed in the rare situations where phlebotomies are not possible either for psychological or technical (poor venous access) reasons. Although desferrioxamine is the only approved drug in this indication, its modalities of administration (prolonged subcutaneous infusions by a portable pump, twelve hours a day and 5 days a week) are rather dissuasive and explain why an oral chelator (such as deferasirox ,may be preferred despite its status of off label medication and some possible side effects (leading to a prescription under the clinician responsibility and with an informed written consent by the patient).

\subsubsection{Therapeutic perspective}

The improved mechanistic knowledge of iron overload development in HC opens the road for applying an innovative approach consisting in hepcidin supplementation. Two main ways are theoretically possible, exogenous administration of hepcidin (minihepcidins(48), full hepcidin, or hepcidin agonists) or endogenous stimulation of hepcidin synthesis by targeting one of the molecular steps involved in the hepcidin synthetic pathway. Normalizing plasma hepcidin levels would restore normal iron homeostasis, and could be indicated as an adjunct to venesections during the induction phase (in order to shorten this phase) or for totally replacing maintenance venesections.

\subsection{Treatment of non-HFE HC}

\subsubsection{Types 2,3 ad $4 \mathrm{~B} \mathrm{HC}$}


Venesection treatment is fully indicated given the phenotype of hepcidin deprivation. Chelation therapy may be associated in case of massive iron overload such as in juvenile $\mathrm{HC}$ (type $2 \mathrm{~A}(49,50)$ and $2 \mathrm{~B})$. Hepcidin supplementation is also a logical perspective (except for type 4B HC characterized by hepcidin resistance).

\subsubsection{Type $4 \mathrm{~A} \mathrm{HC}$}

Venesections remain indicated although their tolerance is less satisfactory than in the group of hepcidin deprivation-related HC. Indeed, given the impairment of cellular iron export, the iron recycling process induced by the venesection procedure is less efficient and exposes to the risk of anemia if the phlebotomy schedule is too strong. Therefore, it is advised to alleviate this schedule and, usually, one venesection every two weeks is feasible and efficient(18). It should be noticed that the plasma ferritin levels reflecting «de-ironing » may be significantly higher than in type 1 $\mathrm{HC}$ (the correlation between plasma ferritin concentrations and tissue iron overload being different) so that iron-MRI can be helpful to get an objective assessment of residual body iron stores. Restoring ferroportin activity in its specific iron export property would represent the future therapeutic approach but still seems a distant prospect.

In conclusion, hemochromatoses are potentially severe diseases, especially because their diagnosis can be ignored during a long asymptomatic period or misdiagnosed due to frequently aspecific clinical expression. Diagnosing $\mathrm{HC}$ is non invasive, based on combined, clinical, biological, and imaging data. HC treatment, mostly based on venesection therapy, is remarkably simple and efficient when considering the global field of genetic diseases. Moreover, for most $\mathrm{HC}$ entities, this symptomatic treatment should, in the 
future, be completed or replaced by hepcidin supplementation. Prevention at the family level, resorting mainly to genetic testing, is essential, and, for HFE-HC, population systematic screening(51) (likely based on combined plasma TfSat and ferritin), although still debated, should remain a major objective. 


\section{ABBREVIATION GLOSSARY}

$\mathrm{HC}$ : haemochromatosis

HAMP :hepcidin antimicrobial peptide

HJV : hemojuvelin

TFR2 : transferrin receptor 2

SLC40A1 : human solute carrier family 40 member1

$\mathrm{CP}$ : ceruloplasmin

HA : hereditary aceruloplasminemia

BMP: bone morphogenetic protein

Smad : Small (phenotype) mothers against decapentaplegic

MAP : mitogen-activated-protein kinase

ERK : extracellular signal-regulated kinase

TfSat : transferrin saturation

NTBI : non-transferrin bound iron

LPI : labile plasma iron

$\mathrm{RPI}$ : reactive plasma iron

GP : general practitioner

MRI : magnetic resonance imaging 
1. Papanikolaou G, Samuels ME, Ludwig EH, MacDonald ML, Franchini PL, Dube MP, Andres L, et al. Mutations in HFE2 cause iron overload in chromosome 1q-linked juvenile hemochromatosis. Nat Genet 2004;36:77-82.

2. Roetto A, Papanikolaou G, Politou M, Alberti F, Girelli D, Christakis J, Loukopoulos D, et al. Mutant antimicrobial peptide hepcidin is associated with severe juvenile hemochromatosis. Nat Genet 2003;33:21-22.

3. Camaschella C, Roetto A, Cali A, De Gobbi M, Garozzo G, Carella M, Majorano N, et al. The gene TFR2 is mutated in a new type of haemochromatosis mapping to 7q22. Nat Genet 2000;25:1415.

4. Njajou OT, Vaessen N, Joosse M, Berghuis B, van Dongen JW, Breuning MH, Snijders PJ, et al. A mutation in SLC11A3 is associated with autosomal dominant hemochromatosis. Nature genetics 2001;28:213-214.

5. Montosi G, Donovan A, Totaro A, Garuti C, Pignatti E, Cassanelli S, Trenor CC, et al. Autosomal-dominant hemochromatosis is associated with a mutation in the ferroportin (SLC11A3) gene. J Clin Invest 2001;108:619-623.

6. Yoshida K, Furihata K, Takeda S, Nakamura A, Yamamoto K, Morita H, Hiyamuta S, et al. A mutation in the ceruloplasmin gene is associated with systemic hemosiderosis in humans. Nature genetics 1995;9:267-272.

7. Brissot $P$, Bardou-Jacquet $E$, Jouanolle $A M$, Loreal $O$. Iron disorders of genetic origin: a changing world. Trends Mol Med 2011;17:707-713.

8. Pietrangelo A. Genetics, Genetic Testing, and Management of Hemochromatosis: 15 Years Since Hepcidin. Gastroenterology 2015;149:1240-1251 e1244.

9. Brissot P, Loreal O. Iron metabolism and related genetic diseases: A cleared land, keeping mysteries. J Hepatol 2016;64:505-515.

10. Pigeon C, Ilyin G, Courselaud B, Leroyer P, Turlin B, Brissot P, Loreal O. A new mouse liverspecific gene, encoding a protein homologous to human antimicrobial peptide hepcidin, is overexpressed during iron overload. J Biol Chem 2001;276:7811-7819.

11. Ganz T. Systemic iron homeostasis. Physiol Rev 2013;93:1721-1741.

12. Drakesmith H, Schimanski LM, Ormerod E, Merryweather-Clarke AT, Viprakasit V, Edwards JP, Sweetland $\mathrm{E}$, et al. Resistance to hepcidin is conferred by hemochromatosis-associated mutations of ferroportin. Blood 2005;106:1092-1097.

13. De Domenico I, Ward DM, Langelier C, Vaughn MB, Nemeth E, Sundquist WI, Ganz T, et al. The molecular mechanism of hepcidin-mediated ferroportin down-regulation. Mol Biol Cell 2007; 18:2569-2578.

14. Ruchala P, Nemeth E. The pathophysiology and pharmacology of hepcidin. Trends Pharmacol Sci 2014;35:155-161.

15. Brissot $P$, Ropert $M$, Le Lan $C$, Loreal $O$. Non-transferrin bound iron: a key role in iron overload and iron toxicity. Biochimica et biophysica acta 2012;1820:403-410.

16. Le Lan C, Loreal O, Cohen T, Ropert M, Glickstein H, Laine F, Pouchard M, et al. Redox active plasma iron in C282Y/C282Y hemochromatosis. Blood 2005;105:4527-4531.

17. Cabantchik ZI, Breuer W, Zanninelli G, Cianciulli P. LPI-labile plasma iron in iron overload. Best practice \& research. Clinical haematology 2005;18:277-287.

18. Le Lan C, Mosser A, Ropert M, Detivaud L, Loustaud-Ratti V, Vital-Durand D, Roget L, et al. Sex and acquired cofactors determine phenotypes of ferroportin disease. Gastroenterology 2011;140:1199-1207 e1191-1192.

19. Miyajima H. Aceruloplasminemia. Neuropathology 2015;35:83-90. 
20. De Domenico I, Ward DM, di Patti MC, Jeong SY, David S, Musci G, Kaplan J. Ferroxidase activity is required for the stability of cell surface ferroportin in cells expressing GPI-ceruloplasmin. EMBO J 2007;26:2823-2831.

21. Allen KJ, Gurrin LC, Constantine CC, Osborne NJ, Delatycki MB, Nicoll AJ, McLaren CE, et al. Iron-overload-related disease in HFE hereditary hemochromatosis. N Engl J Med 2008;358:221-230.

22. Warne CD, Zaloumis SG, Bertalli NA, Delatycki MB, Nicoll AJ, McLaren CE, Hopper JL, et al. HFE p.C282Y homozygosity predisposes to rapid serum ferritin rise after menopause: a genotypestratified cohort study of hemochromatosis in Australian women. J Gastroenterol Hepatol 2016.

23. Desgrippes R, Laine F, Morcet J, Perrin M, Manet G, Jezequel C, Bardou-Jacquet E, et al. Decreased iron burden in overweight $\mathrm{C} 282 \mathrm{Y}$ homozygous women: Putative role of increased hepcidin production. Hepatology 2013;57:1784-1792.

24. Latour C, Kautz L, Besson-Fournier C, Island ML, Canonne-Hergaux F, Loreal O, Ganz T, et al. Testosterone perturbs systemic iron balance through activation of epidermal growth factor receptor signaling in the liver and repression of hepcidin. Hepatology 2014;59:683-694.

25. Bachman E, Feng R, Travison T, Li M, Olbina G, Ostland V, Ulloor J, et al. Testosterone suppresses hepcidin in men: a potential mechanism for testosterone-induced erythrocytosis. J Clin Endocrinol Metab 2010;95:4743-4747.

26. Stickel F, Buch S, Zoller H, Hultcrantz R, Gallati S, Osterreicher C, Finkenstedt A, et al. Evaluation of genome-wide loci of iron metabolism in hereditary hemochromatosis identifies PCSK7 as a host risk factor of liver cirrhosis. Hum Mol Genet 2014;23:3883-3890.

27. Brissot P. Optimizing the diagnosis and the treatment of iron overload diseases. Expert Rev Gastroenterol Hepatol 2016;10:359-370.

28. Ong SY, Nicoll AJ, Delatycki MB. How should hyperferritinaemia be investigated and managed? Eur J Intern Med 2016;33:21-27.

29. Martinelli N, Traglia M, Campostrini N, Biino G, Corbella M, Sala C, Busti F, et al. Increased serum hepcidin levels in subjects with the metabolic syndrome: a population study. PLoS One 2012;7:e48250.

30. Deugnier Y, Laine F. [Dysmetabolic iron overload syndrome: a systemic disease?]. Presse Med 2014;43:625-627.

31. Moirand R, Lescoat G, Delamaire D, Lauvin L, Campion JP, Deugnier $Y$, Brissot P. Increase in glycosylated and nonglycosylated serum ferritin in chronic alcoholism and their evolution during alcohol withdrawal. Alcohol Clin Exp Res 1991;15:963-969.

32. Wood JC. Estimating tissue iron burden: current status and future prospects. Br J Haematol 2015;170:15-28.

33. St Pierre TG, Clark PR, Chua-anusorn W, Fleming AJ, Jeffrey GP, Olynyk JK, Pootrakul P, et al. Noninvasive measurement and imaging of liver iron concentrations using proton magnetic resonance. Blood 2005;105:855-861.

34. Gandon Y, Olivie D, Guyader D, Aube C, Oberti F, Sebille V, Deugnier Y. Non-invasive assessment of hepatic iron stores by MRI. Lancet 2004;363:357-362.

35. Saliba A, Taher A. Iron overload in transfusion-dependent thalassemia. Hematology 2015;20:311-312.

36. Musallam KM, Rivella S, Vichinsky E, Rachmilewitz EA. Non-transfusion-dependent thalassemias. Haematologica 2013;98:833-844.

37. Aubart M, Ou P, Elie C, Canniffe C, Kutty S, Delos V, Graffigne C, et al. Longitudinal MRI and Ferritin Monitoring of Iron Overload in Chronically Transfused and Chelated Children With Sickle Cell Anemia and Thalassemia Major. J Pediatr Hematol Oncol 2016;38:497-502.

38. Steensma DP, Gattermann N. When is iron overload deleterious, and when and how should iron chelation therapy be administered in myelodysplastic syndromes? Best Pract Res Clin Haematol 2013;26:431-444.

39. Sirvent A, Auquier P, Oudin C, Bertrand $Y$, Bohrer $S$, Chastagner $P$, Poiree $M$, et al. Prevalence and risk factors of iron overload after hematopoietic stem cell transplantation for childhood acute leukemia: a LEA study. Bone Marrow Transplant 2016. 
40. Ghoti H, Rachmilewitz EA, Simon-Lopez R, Gaber R, Katzir Z, Konen E, Kushnir T, et al. Evidence for tissue iron overload in long-term hemodialysis patients and the impact of withdrawing parenteral iron. Eur J Haematol 2012;89:87-93.

41. Porto G, Brissot P, Swinkels DW, Zoller H, Kamarainen O, Patton S, Alonso I, et al. EMQN best practice guidelines for the molecular genetic diagnosis of hereditary hemochromatosis $(\mathrm{HH})$. Eur $\mathrm{J}$ Hum Genet 2016;24:479-495.

42. Bardou-Jacquet E, Ben Ali Z, Beaumont-Epinette MP, Loreal O, Jouanolle AM, Brissot P. NonHFE hemochromatosis: pathophysiological and diagnostic aspects. Clin Res Hepatol Gastroenterol 2014;38:143-154.

43. Wallace DF, Subramaniam N. The global prevalence of HFE and non-HFE hemochromatosis estimated from analysis of next-generation sequencing data. Genet Med 2015;Pubmed ahead of print.

44. Detivaud L, Island ML, Jouanolle AM, Ropert M, Bardou-Jacquet E, Le Lan C, Mosser A, et al. Ferroportin diseases: functional studies, a link between genetic and clinical phenotype. Hum Mutat 2013;34:1529-1536.

45. HAS. French recommendations for management of HFE hemochromatosis. Haute Autorité de Santé 2005; www.has-sante.fr.

46. Brissot P, Ball S, Rofail D, Cannon H, Jin VW. Hereditary hemochromatosis: patient experiences of the disease and phlebotomy treatment. Transfusion 2011;51:1331-1338.

47. Rombout-Sestrienkova E, Winkens B, Essers BA, Nieman FH, Noord PA, Janssen MC, van Deursen $\mathrm{CT}$, et al. Erythrocytapheresis versus phlebotomy in the maintenance treatment of HFE hemochromatosis patients: results from a randomized crossover trial. Transfusion 2016;56:261-270.

48. Ramos E, Ruchala P, Goodnough JB, Kautz L, Preza GC, Nemeth E, Ganz T. Minihepcidins prevent iron overload in a hepcidin-deficient mouse model of severe hemochromatosis. Blood 2012;120:3829-3836.

49. Maeda T, Nakamaki T, Saito B, Nakashima H, Ariizumi H, Yanagisawa K, Hattori A, et al. Hemojuvelin hemochromatosis receiving iron chelation therapy with deferasirox: improvement of liver disease activity, cardiac and hematological function. Eur J Haematol 2011;87:467-469.

50. Santos PC, Cancado RD, Pereira AC, Chiattone CS, Krieger JE, Guerra-Shinohara EM. HJV hemochromatosis, iron overload, and hypogonadism in a Brazilian man: treatment with phlebotomy and deferasirox. Acta Haematol 2010;124:204-205.

51. de Graaff B, Neil A, Sanderson K, Yee KC, Palmer AJ. Costs associated with hereditary haemochromatosis in Australia: a cost-of-illness study. Aust Health Rev 2016. 


\section{FIGURE LEGENDS}

FIGURE 1. From mutations to hypersideremia ; molecular and biochemical cascades. TFR2: transferrin receptor 2 ; HJV : hemojuvelin ; MAPK/ERK : mitogen-activated protein kinase / extracellular signal-regulated kinase ; BMP/SMAD : bone morphogenetic protein / small (phenotype) mothers against decapentaplegic.

FIGURE 2. From mutations to cellular iron excess ; biological cascade.

FIGURE 3. Diagnostics steps for HFE and non-HFE haemochromatosis.

FIGURE 4. Present and future therapeutic approaches for HFE and nonHFE haemochromatosis. 


\section{Figure}

Click here to download high resolution image

FIGURE 1

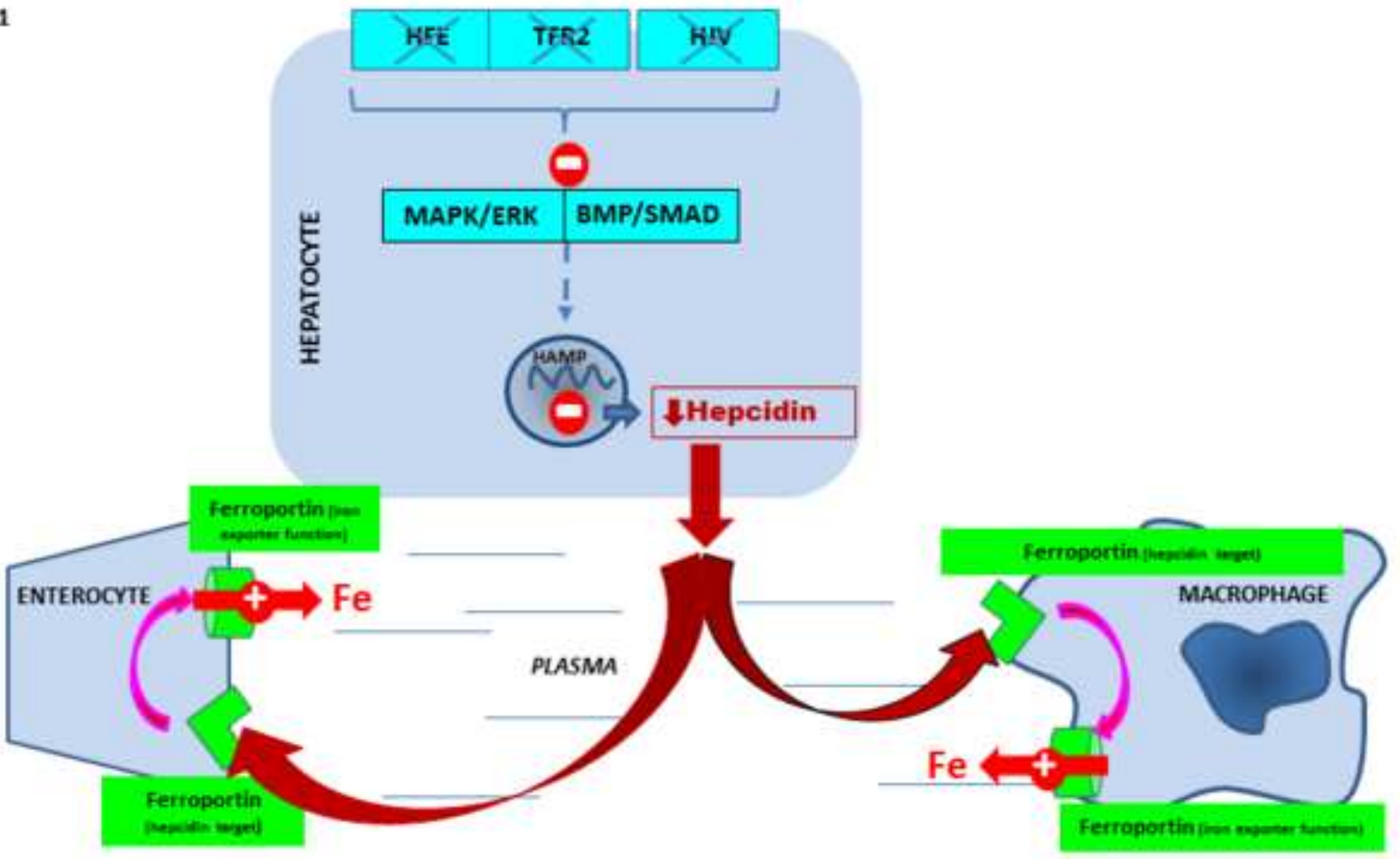


Click here to download high resolution image

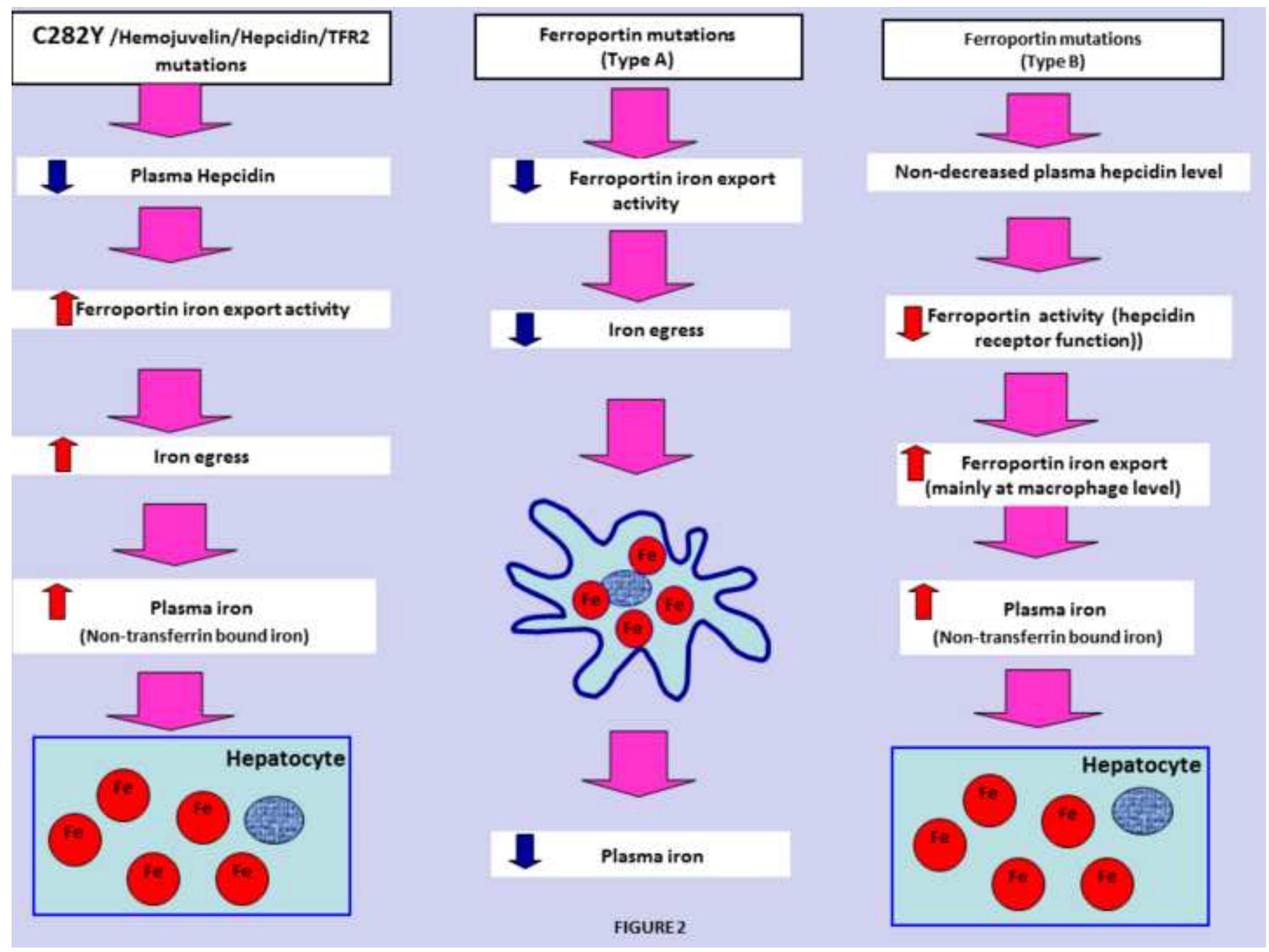




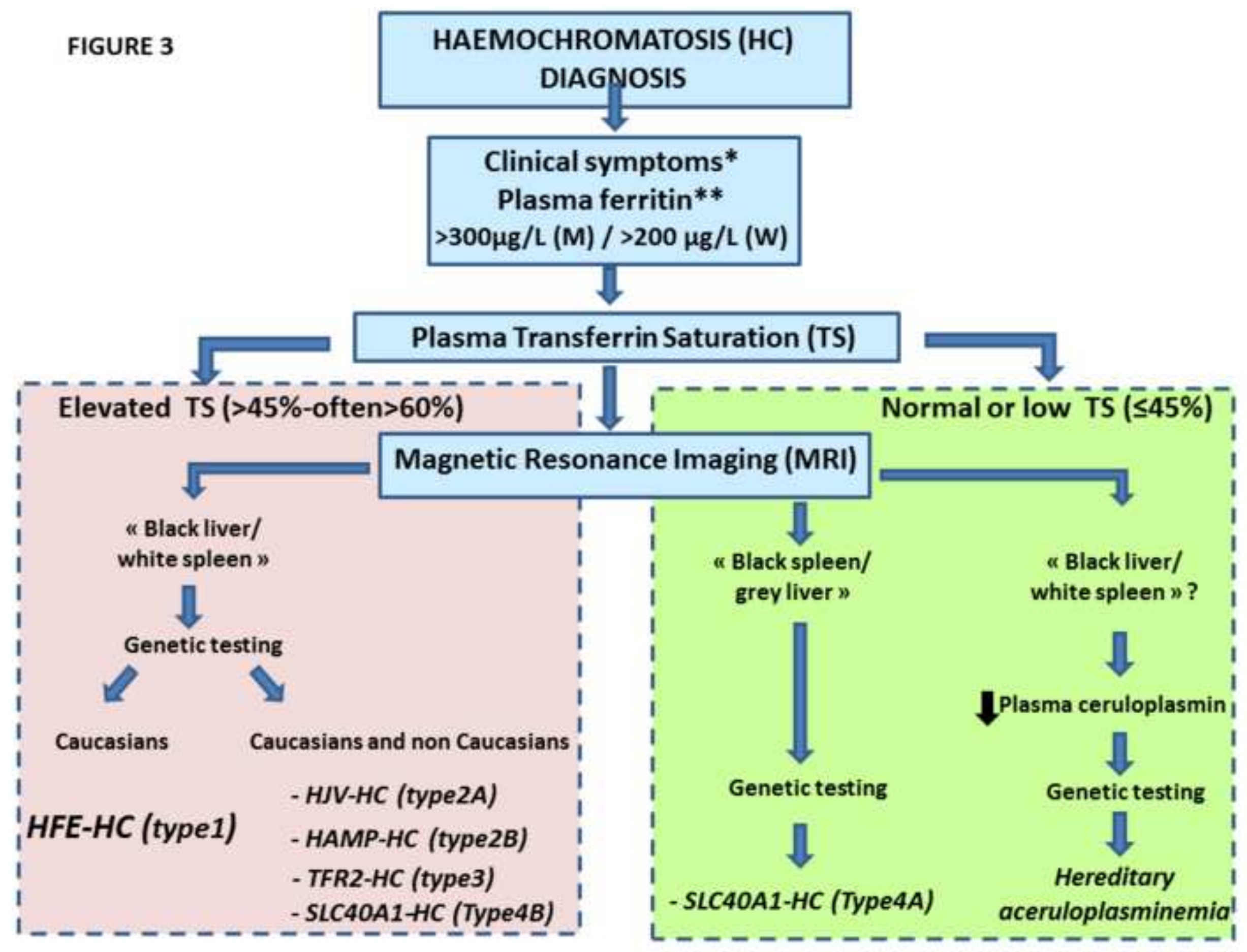


FIGURE 4

Hepcidin deprivation
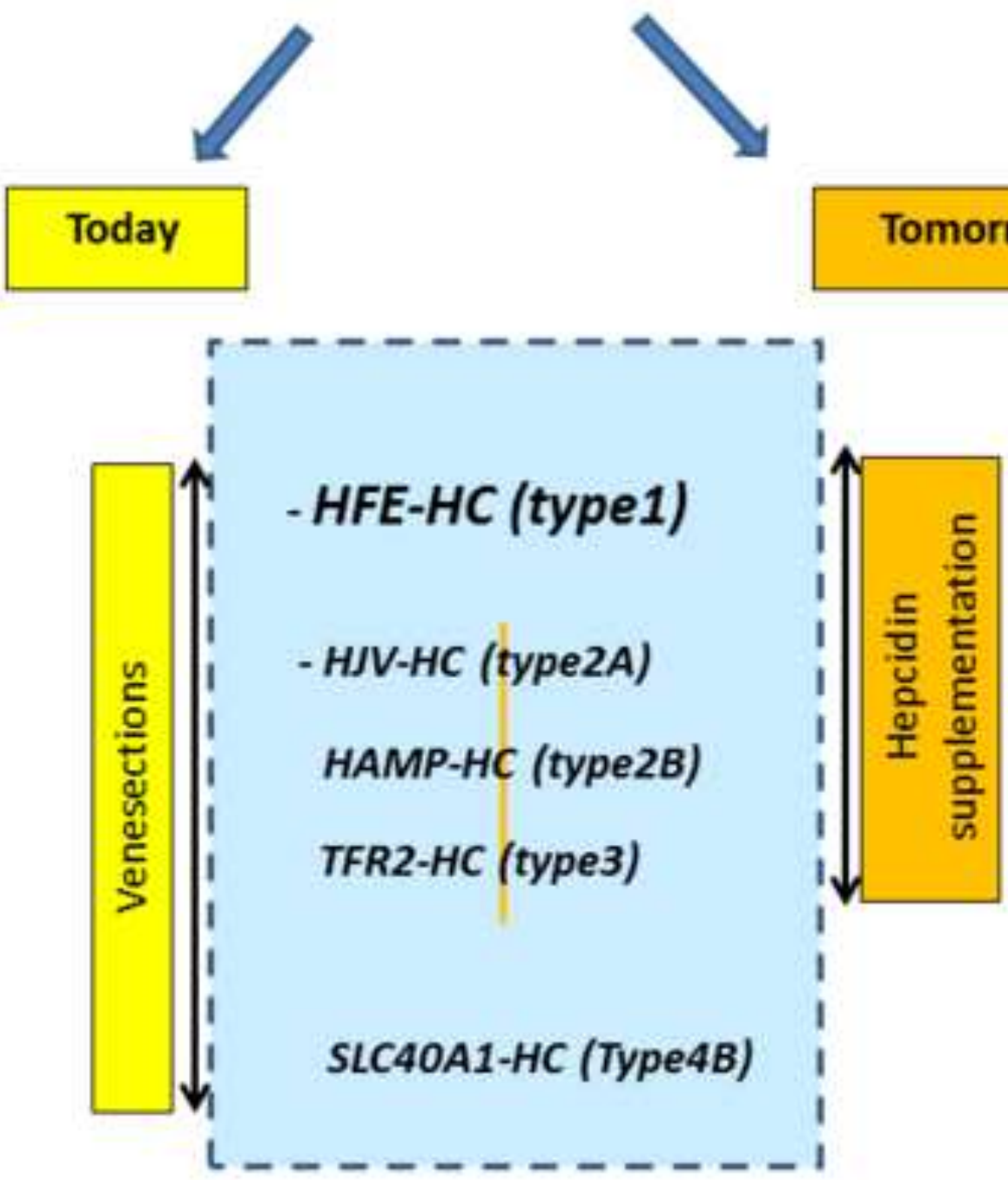

HAEMOCHROMATOSIS (HC) TREATMENT

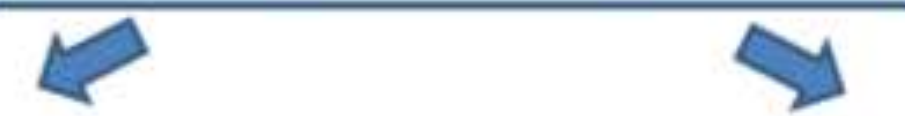

Ferroportin deficiency (iron export dysfunction)

SLC4OA1-HC (Type4A)

\section{Tomorrow}

Venesections \pm
Tomorrow

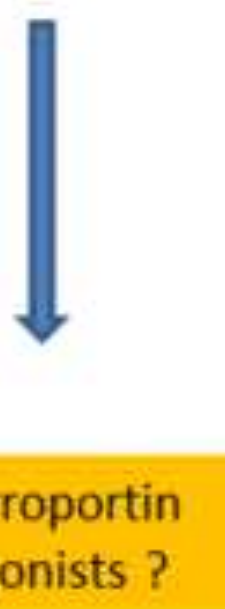

